This is an author produced version of a book chapter published in "Multifunctional Land Use: meeting future demands for landscape goods and services". This book chapter includes the final publisher proofcorrections but not the publication's pagination.

Citation for the published chapter:

Skärbäck, E. (2007) Planning for healthful landscape values. In: Mander, Ü., Wiggering, H., \& Helming, K. (eds.) Multifunctional Land Use: meeting future demands for landscape goods and services. pp. 305-326. SpringerVerlag Berlin-Heidelberg.

Access to the published version may require institutional subscription. Published with permission from: Springer Verlag.

Information about the original publication can be found at: http://www.springer.com/geography/human+geography/book/978-3-540$\underline{36762-8}$

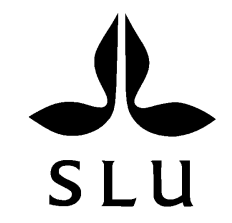

Epsilon Open Archive http://epsilon.slu.se 


\title{
Planning for healthful landscape values
}

\author{
Erik Skärbäck \\ Department of Landscape Planning Alnarp, SLU, Sweden
}

\section{Introduction}

This paper focuses on how we may balance the health functions of nature and landscape values in development planning. The concept "balance" implies discussing measures to mitigate, minimize and compensate for negative impacts. In this context, negative impact is understood as a disturbance by development projects of resources that improve people's health. The resources may be both existing nature and landscape values and potential, as yet undeveloped, landscape qualities. The health functions are defined using scientific studies in environmental medicine and environmental psychology. This paper presents cases that have applied such scientific results to the planning of housing and infrastructure in two development projects in southwestern Sweden, the towns of Lomma and Àkarp. Evaluations of health functions in these projects constitute an important part of the process of designing and analyzing impacts, and the process of negotiating mitigation measures as conditions for permits granted by the municipalities, the county administration and the government of Sweden. In the long run, this research will hopefully lead to a growing awareness among the public, developers and politicians about improving the health aspect as a parameter for sustainable development.

\subsection{Background}

People reduce their stress significantly when exposed to health-promoting nature and landscape values. A high level of traffic noise increases stress. This paper discusses a way of integrating consideration of health aspects into development planning. Compensation measures to mitigate negative impacts on nature and landscape have long been used to balance the loss of ecological functions in development projects. This paper focuses on how we may balance the health functions of nature and landscape. 


\subsection{Balancing and compensation measures}

Compensation measures have been used in Germany (Berlin) since 1976, before EIA was established there. Such measures then became part of the German Environmental Act, and are now also part of the German Building Act. A review of the use of environmental compensation in planning in five different countries - Germany, the US, The Netherlands, the UK and Sweden - was carried out by Rundcrantz and Skärbäck (2003). The review shows that all studied countries focus on ecological values, but in the UK there is also a focus on landscape scenery and amenities. The review also shows that the degree of legal support is strong in Germany and the US, somewhat strong in The Netherlands, but less clear in the UK and Sweden. In Sweden, there is no special legislation, except a few paragraphs in the Environmental Code and regulations for roads. What we hope to provide in the overall program "Landscape as a resource" is a stronger focus on values for recreation and health. The use of compensation measures is sometimes described as the balancing method, which has been under development at the university level in Sweden since the mid 1990s (Skärbäck 1997).

\subsection{Green area factor}

Reaching a balance cannot ensure a sufficient environmental standard for a development area. Especially in situations where the initial existing values are more limited than the future demands for the development (e.g. former industrial sites), there may be a need to define a minimum standard of biotope qualities. The "green area factor" is such a parameter. It was developed to enable negotiation and decisions on a minimum standard for granting a building permit. The method is normally implemented in the designing phase at block level, and if well used may be an inspiring precondition for creative architects who wish to integrate nature and culture. The method was originally developed in Germany, and was first used in Sweden in 2001, at the annual housing exhibition Bo01 in Malmö. The green area factor is a tool that may be used in all developing areas to set the target standard for biological quality.

\subsection{Environmental psychology}

What evidence is there to support the statement that people reduce their stress significantly when exposed to positive nature and landscape values? The relationship between the green structure and health in urban areas was illustrated by Ottosson and Grahn (1998). Another investigation shows that 
people are greatly afflicted by stress-related illnesses (Grahn and Stigsdotter 2003). A third study illustrates the importance of having a park very close to your home. People who visit green areas seem to recover more quickly from stress-related afflictions (Ulrich 1991). Distance to the closest open green urban area from the home is of great importance in determining how often people visit open green urban areas. The further from home you have to walk to find the closest open green area, the more seldom you will visit such an area. And the more often people visit such places, the less frequently they feel stressed, irritated and fatigued (Stigsdotter and Grahn 2004; Grahn and Stigsdotter 2003). A critical distance seems to be 300 meters from home to the nearest open green urban area. However, after only 50 meters the frequency of visits falls and the level of stress rises (Ibid.).

At SLU Alnarp, a group of researchers have developed eight experienced qualities or characteristics of open green urban areas that are of great importance for people's preferences and well-being (Grahn and Berggren-Bärring 1995; Stigsdotter and Grahn 2003; Grahn et al. 2005). These eight characteristics may be summarized as follows:

1. Serene Peace, silence and care. Sounds of wind, water, birds and insects. No rubbish, no weeds, no disturbing people.

2. Wild Fascination with wild nature. Plants seem selfsown. Lichen and moss-grown rocks, old paths.

3. Lush Rich in species. A room offering a variety of wild species of animals and plants.

4. Spacious A room offering a restful feeling of "entering another world", a coherent whole, like a beech forest.

5. The Common A green open place admitting of vistas and stay.

6. The Pleasure Garden A place of imagination. An enclosed, safe and secluded place where you can relax and be yourself, let your children play freely and also experiment.

7. Festive A meeting place for festivity and pleasure.

8. Culture The essence of human culture: A historical place offering fascination with the course of time.

Three of the characteristics have been shown to be of particular importance for restoring people's mental capacity: Serene, Space and Wild (Grahn et al. 2005; Stigsdotter 2005). A feeling of serenity may be assumed to be correlated with the absence of noise. It may also be assumed that a feeling of space - of entering into another world - is disturbed by traffic noise. In the same way, it may be assumed that all man-made noise and all kinds of 
man-made sounds destroy the feeling of being in the wild. Traffic planners have expressed the notion that even people in the countryside hear high sound levels. Such high sound levels may come from waves breaking on the shoreline, but they do not ruin the experience of being in wideopen spaces - quite the contrary in fact. The feeling of security has also shown a high correlation with noise (Grahn and Berggren-Bärring, 1995), and there are huge gender differences regarding measures of feelings of security in urban outdoor areas (Grahn and Larsson 1997).

One important factor for public health is the lack of facilities for restorative experiences after a stressful day. Risk factors are expected to largely explain why so many people in Sweden are put on protracted sick leave - a situation which today incurs enormous expenses for Swedish society - for illnesses ranging from acute head and back ache, burnout syndrome, depressions, high blood pressure, non-insulin-dependent diabetes mellitus, heart diseases and obesity (Atkinson et al. 1996). Walks in urban parks and open green areas may act as preventive measures for illnesses caused by a sedentary lifestyle as well as illnesses caused by high stress levels in people's everyday lives. Moreover, rich and poor, men and women, boys and girls from all social classes take walks in urban parks and open green areas, because this activity is inexpensive and highly appreciated. Consequently, open green urban areas may be regarded as a democratic resource in health promotion (Grahn and Stigsdotter 2003).

Our knowledge regarding the optimum size, shape and function of urban green areas with respect to human welfare and biodiversity is, however, still lacking. Also few studies have been conducted that look at both preferences for moving from home to urban parks or other attractions and the barriers to such movement. Quantitative questionnaire surveys usually show that long distances and busy roads and railways act as important barriers, hindering people from visiting attractive places in towns (Grahn 1991; Grahn and Larsson 1997). In addition, qualitative in-depth interviews and focus group interviews show that security, i.e., protection from traffic or from being molested, and experienced qualities are of great importance in deciding whether or not to visit an urban green open space (Grahn, 1991 1994; Berggren-Bärring and Grahn 1995; Grahn and Larsson 1997). Research from Australia on environmental factors associated with walking shows a promising, although at this stage limited, pattern of positive findings. The aesthetic nature of the local environment, the convenience of facilities for walking (footpaths, trails), the accessibility of places to walk to (shops, beach), level of traffic roads, and composites of environmental attributes have all been found to be associated with walking for particular purposes (Owen et al. 2004). 


\subsection{Noise level regulations in planning}

Traffic-related noise constitutes a major part of community noise, and is an important environmental health problem. Health effects are worse for certain vulnerable groups such as children (UNCED 1992; Evans 1998), persons with hearing defects and shift workers. There is also fairly consistent evidence that noise above $80 \mathrm{dBA}$ causes reduced helping behavior.

In the process of planning the physical environment, the application of different noise regulations and guidelines is the subject of continuous and lively discussion. Recommended target values for traffic noise outside residential buildings are LAeq, $24 \mathrm{~h}<55 \mathrm{~dB}$ and LAmax $70 \mathrm{~dB}$, according to Swedish Government decisions. Because data show that noise from road traffic causes more extensive annoyance reactions than railway noise, a "bonus" of $5 \mathrm{~dB}$ has been applied for railway noise in Sweden (i.e. LAeq, 24h $60 \mathrm{~dB}$, outdoor guideline value). Such a bonus can be questioned in cases in which the train traffic has reached a very high frequency. Nevertheless, it is difficult to compare equivalent measures for car traffic versus train traffic.

The target value for parks and green areas is also LAeq, $24 \mathrm{~h} 55 \mathrm{~dB}$. This target value has been formulated by the Swedish Environmental Protection Agency (BRÅD, Buller från vägtrafik, Allmänna råd remissutgåva, Naturvårdsverket 1991). However, it has not been ratified by governmental decision and is therefore commonly ignored or given less consideration in plans and new road and railway construction projects. The Swedish Road Administration (Publikation 2001:88 Bullerskyddsåtgärder - allmänna råd för Vägverket) and the Swedish Rail Administration, which has responsibility for the entire railway system in Sweden (Buller och vibrationer från spårburen linjetrafik - policy och tillämpning [BVPO 724.001] February 1997), specify the same target value (55 dBA) as a noise protection goal for recreational settings in densely populated areas and $40 \mathrm{dBA}$ for forests and undeveloped environments intended for outdoor recreational activities. At international levels, there are also recommendations (without specifying target values) that impose rigorous demands on low sound levels in parks and forest environments (Berglund et al. 2000)). In addition, the EU directive asserts the importance of protecting "quiet" areas (the EU directive for community noise 2002/49/EG).

The zonal noise boundaries that separate roads and railways from residential areas are often defined in building plans as parks, but should be seen as noise-exposed park areas. With wide dense vegetation $(>60 \mathrm{~m})$, they can provide some protection against noise. However, the recreational value of this kind of park area is very low, as the sound levels are usually 
far higher than $55 \mathrm{dBA}$. It is possible that such park areas are instead perceived as part of the road and railway barrier.

The adverse health effects of noise are being studied within a multidisciplinary research program entitled "Soundscape Support to Health," which is being supported by grants from the Swedish Foundation for Strategic Environmental Research (MISTRA) during the period 2000 2007 (Öhrström et al. 2005a). Results show that residents chronically exposed to high traffic noise (LAeq, $24 \mathrm{~h} \geq 60 \mathrm{~dB}$ ) and without access to a quiet side of the dwelling (LAeq, $24 \mathrm{~h}<45 \mathrm{~dB}$, free field level) report stressrelated symptoms more frequently than do residents living in quiet building areas (LAeq, $24 \mathrm{~h}<45 \mathrm{~dB}$, free field level). One of the most important findings of the research program, obtained, for example, through studies of the municipality Lerum outside Gothenburg, is the need to use a noise-action strategy that considers the "total sound environment" (i.e. all noise sources and perceptions of them) and not just one noise source at a time, which is the praxis today (Öhrström et al. 2005a,b).

\subsection{Cost-benefit analysis}

Cost-benefit analyses (CBA) for infrastructure planning and investments include noise effects on residential housing. Noise in parks and other outdoor recreation areas and footpaths is not considered in current state-ofthe-art CBA, due to lack of reliable monetary valuation methods. The monetary valuation of noise includes certain health effects in residential settings, but for parks and recreation areas the noise-related health effects are not considered in the model (Eliasson et al. 2002). However, research on the connection between visits to parks and stress reduction shows a strong preference for the serene quality of parks (Eliasson 2005). One hypothesis is that we are close to being able to start quantifying the environmental costs associated with the level of noise in parks.

\subsection{Issue, hypothesis and aims}

This paper deals with the issue of how people's needs and demands for certain landscape and park qualities can be considered in housing and infrastructure planning. My hypothesis is that such needs can be defined as planning criteria, that corresponding landscape qualities can be evaluated in development areas such that they have a significant influence on the design process and on the choice between alternative solutions, and that compensation measures and green area factors can be negotiated and decided upon as a minimum quality standard for the development project. 
These standards can then be formulated as conditions in the planning regulation in the EIR process and when granting permits.

The overall research program, from which this paper originates, is called "Landscape as a resource for health and development in the Öresund Sound Region" (EU, Interreg III). The research program is based on a number of presuppositions:

- In modern society, well-educated people search for a good place to live for themselves and their children. Employers have to follow.

- An attractive business park region may be easily overexploited and lose its attraction.

- The Prime ministers of Sweden and Denmark have, in connection with the opening of the bridge between Sweden and Denmark, jointly expressed that the Öresund Sound Region shall remain one of the cleanest regions in Europe.

- We believe that nature and parks with certain qualities and low noise disturbance fulfill important demands for stress reduction and creativity at work. We also believe in the opposite perspective, thus that lack of nature and parks in your neighborhood as well as a high level of noise increase the risk of stress-related illnesses and arrested creativity.

- When working with a transnational region crossing the boarder of two countries, it is difficult to fulfill mutual physical planning that reaches all the way to a politically mandated, overall comprehensive plan. However, one of our hypotheses, as a binational research group, is that if we can show the importance of certain recreation values for the development, then we may reach some consensus among the planners, politicians, developers and investors in the region concerning how to implement the landscape in the ongoing urban planning.

The objective of developing the Sound Region as one of the most attractive regions in Europe - considered both from an economic, production and an environmental point of view - constitutes a major challenge for planners, researchers and all kinds of stakeholders within the region. This challenge is particularly demanding due to the many contrasting interests and to the high development rate. In fact, the region is developing at a speed that sometimes exceeds that of traditional planning procedures. The population in the whole Region, which used to be defined as the County of Skåne on the Swedish side and the Island of Zeeland on the Danish side, is growing at a rate of 30,000 people a year. The region holds great potential with respect to nature and amenity values. Moreover, the educational level of the population helps to create favorable conditions for high-tech industries. Despite the great potential of the region, development may 
deteriorate nature and amenity values and thus reduce the general qualities of the region.

\section{Method}

When trying to implement the eight characteristics in planning, there are often discussions of how those characteristics that correspond to basic human needs should be translated and implemented in actual practice in different projects with different preconditions. In the program 'Landscape as a resource for health and development in the Öresund Sound region' the discussion is based on two perspectives: academic researchers starting from a theoretical point of view and municipal staff implementing the theories in practice from a methodological point of view. Case studies have been conducted on both municipal level (Malmö, Svedala, Lomma and Burlöv) and regional level (Skåne/Zeeland).

To improve this translation to reality, experiments are being conducted in developing public participation. One $\mathrm{PhD}$ student in the program, Niclas Östlund, is investigating the possibility of conducting interviews over the Internet. His aims are to: evaluate preferences in a geographical perspective using GIS maps, communicate planning concepts and achieve a dialogue with the public (Östlund 2005).

Two case studies were adopted in co-operation with two municipalities (Burlöv and Lomma) northeast of Malmö. The zone from Malmö to Lund has reached particularly high accessibility after the opening of the bridge between Copenhagen and Malmö (Figure 1). The case studies were carried out by a research group at the Department of Landscape Planning in Alnarp, SLU. Some experiments were also conducted by students enrolled in the course "Large Projects" (2004) at the Landscape Architectural Program of the university. The case studies are of two kinds: In Lomma, designing for development of housing on previous industrial sites at the sea front, and in the municipality of Burlöv, environmental impact analysis of a project extending a railroad from two to four tracks directly through the small town of Åkarp. 




Figure 1. Malmö-Åkarp-Lund as a part of the "Greater Copenhagen" (adapted from Törnqvist 1978).

The impact analyses are focused on the recreational values and functions, not primarily on the ecological aspects. One aim in the planning is that sufficient values of the eight characteristics should be present and available for the population, and not at a great distance. Criteria concerning what the proper measures of area and distance are for each characteristic have not yet been formulated. Also left to be formulated are specific lists of landscape qualities that correspond to certain characteristics in certain situations. More empirical studies, experiments and case studies are needed to obtain sufficient numbers of experiences and references to eventually formulate some general criteria. Until then, each case must be evaluated using a kind of holistic approach in discussions between researchers and people concerned, such as planning officers at the municipality. The use of experiments involving interviews conducted, among other ways, over the Internet is one way to broaden the basis for defining the characteristics. Thus far we have formulated one criterion: There should be more and better landscape values after the development than before within and/or in close proximity to the planning area.

The question is always open of how we can balance using compensation measures for negative impacts of the development. The first step is to try to avoid negative impacts by changing in the overall design in the very 
early planning phases. The second step is to minimize as much as possible impacts that cannot be fully avoided. The third step is to compensate with restorative measures for the values and functions (the specific characteristics) disrupted at the place concerned. The fourth step is to carry out other kinds of compensation measures corresponding to other values and functions and/or at other places (Figure 2).

1. Avoiding

2. Minimizing

3. Restorment compensation measures For the affected function in the right functional context

4. Replacement compensation measures with another function in the area, or with the right function in another area

Figure 2. Balancing negative impacts (Rundcrantz and Skärbäck 2003).

If the qualities present before development are poor, as for example in previous industrial areas, then claims for improvements will be high. The principle of balancing 'to compensate for negative impacts on values and functions by creating new values to ensure the same function after the development' is not enough, but could be combined with the use of a 'green area factor'. Using a green area factor, it is possible to define a minimum standard of green qualities that can be decided upon among authorities as a condition for granting a building permit.

The green area factor aims at reflecting an area's contribution to biodiversity. The green area factor is an imaginary green area that is divided by the total lot area. The imaginary green area is calculated by multiplying every sub-area (of the total lot) by a factor between 0 and 1 , defined for each kind of urban biotope (Jacobsson 2004). The sum of all imaginary green spaces makes up the total imaginary green space. By setting an objective for the total imaginary green space, the indicator may be used in relation to level of possible biodiversity. The requirement for housing areas, schools and kindergartens used to be set to a green area factor of 0.6 , and for commercial areas 0.3. 


\section{Result - Case studies}

As a whole, four municipality case studies are underway in the Interreg project. This paper presents two of them. Evaluation of the eight characteristics before and after a planned development project constitutes a common thread through all the cases studied.

\subsection{Lomma municipality - Lomma Harbour housing project}

The Lomma Harbour housing project is situated very attractively behind the sandy Lomma Beach, where a river meets the Sound. Previously, the area was a landfill partly for an industry producing the building material Eternite, consisting of asbestos, and partly for disposing of waste. The area has potential to attract residents from the entire Öresund Sound Region, or the "Greater Copenhagen Region" (as some Danish PR firms prefer to call the region). The present inhabitants of Lomma also expect the development to improve the attraction of the area for promenades and leisure activities. The present design of the development area is a result of an architect competition finished 2001 before our case study started. Some early environmental studies were carried out, e.g., a "Village analysis". Quality conditions were defined through an Architectural Quality Program based on the winning concept, and regulated in a PPP-contract between the developers and the municipality, which also includes the necessary concerns caused by the contaminated soil from the former industrial activities. A balancing study investigating the whole area was commissioned by the municipality of Lomma. The study focused on biotopes and landscape values. The working procedure started with an inventory, continued with an evaluation of the winning architectural design with regard to impacts on the inventoried values and the estimation of benefits from measures, new values, in the proposed design. The investigation revealed that the total development area reached a positive balance, although some separate parts of the development site reached a "large plus" and others a "minus" (Skärbäck 2003).

Later in our research project, we investigated the area with respect to the eight characteristics before and after the development (Figure 3). 


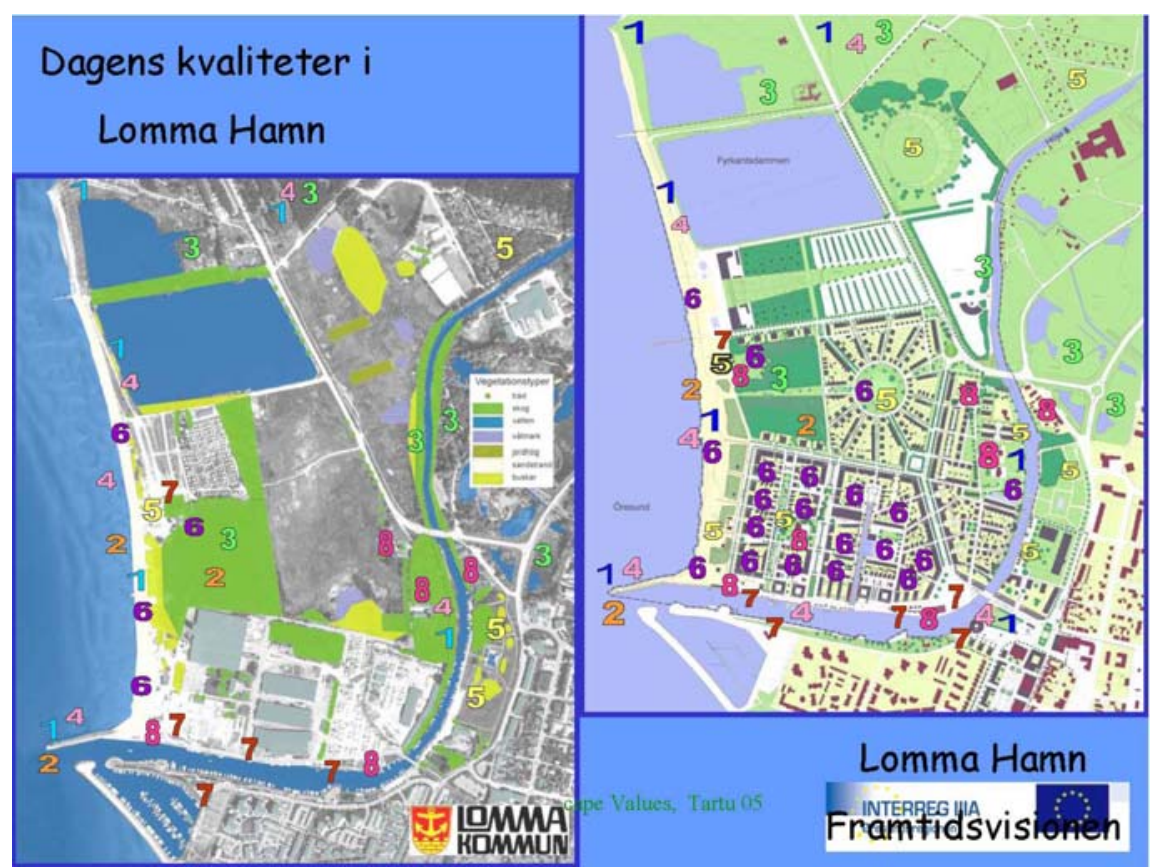

Figure 3. The eight characteristics before and (estimated) after planned development (Gladys Fuentes, Lomma; Skärbäck 2003).

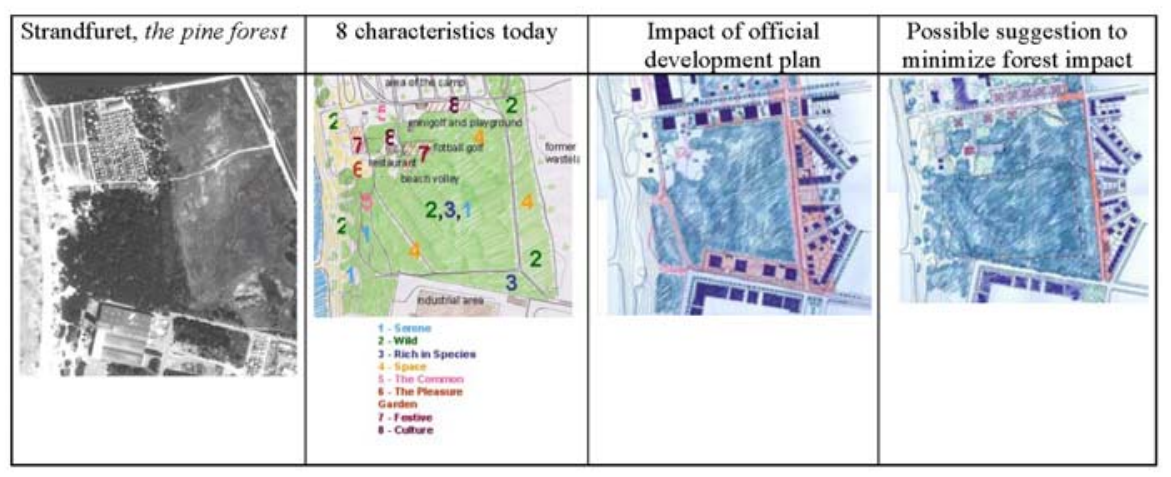

Figure 4. Analysis of values, impact and possible mitigation measure for the pine forest, "Strandfuret", of Lomma Harbour housing development project (Benediková 2004).

The result was an expected increase in the characteristics "Pleasure" (6), "the Common" (5) and "Festive" (7), but a decrease in "Serene" (1) and 
"Wild" (2). The characteristics "Rich in Species" (3) and "Space" (4) were estimated not to have decreased, as the development provides opportunities for bringing in new plants, insects and birds (3) and the future variety of housing characters, e.g., a "garden city", a "harbor city" and "beach blocks" provides opportunities for creating new rooms that give a feeling of entering another world. One criterion for achieving this, however, is of course full accessibility throughout the different housing districts. Thus, no gated cities are allowed. The increase in the more social characteristics $(5$, 6 , and 7) was expected, given the development of a former industrial area into a proper housing district. The decrease in the more nature-oriented characteritics (1 and 2) was somewhat surprising, as the existing pine forest was intended to be saved. The detailed inventory and impact analysis, however (Benediková 2004), exposed losses in the fringe zone of the forest (Figure 4). A conclusion is that detailed inventories, analyses and accounts of natural and cultural resources are necessary to discover losses of values.

\subsection{Burlöv municipality - Widening the railroad through Åkarp}

The characteristic serene - seen in parks - has been the main focus of study in this case.

Right in the middle of the communication funnel of southwestern Sweden, where all transportations between Scandinavia and Europe has to pass, lies the second smallest municipality in Sweden: Burlöv. One of its two towns is Åkarp. Alnarp, part of the University SLU, is close, one kilometer west of Åkarp. Åkarp (pop. 6,500) has a rich cultural history and is perceived as a nice place to live, only ten kilometers from Malmö and Lund. From Åkarp people can reach three universities in less than 10 minutes. Today, the city is surrounded by one motorway (E6) to the west (Alnarp is situated on the other side of E6, just south of the town Lomma), and another motorway (E22) to the southwest. The traffic has increased greatly over the past 40 years and for the park at Alnarp, the noise has increased to an unacceptable $60 \mathrm{dBA}$ during daytime. The capacity of the railroad passing right through the settlements has reached its threshold and must be widened from 2 to 4 tracks. The Harbor of Malmö shall expand and double its size from 1.5 million $\mathrm{m}^{2}$ to 3.0 million $\mathrm{m}^{2}$ to serve as the main harbor for all the Greater Copenhagen Region including Malmö. Both cities have merged their Harbor companies to one, the CM Port. The very large Malmö railway station has developed during recent years into an international shunting node in Sweden. The larger cities Malmö and 
Lund do not want freight traffic trough their urban areas. They want an "Outer railroad track" around both cities (EIR 2004). The consequence will be that freight trains may pass right through the municipality of Burlöv ( $\AA$ karp and Arlöv) twice back and forth in the distant future.

The present situation is a maximum noise level of fast passing trains at a total time of one (1) hour per day, and there are no noise barriers at all today. The state-owned railroad company (Banverket) wants to broaden the corridor at the present ground level, surface terrace alternative, and argues that the future situation will be better than before, but it will not fulfill the target value for parks and green areas, $55 \mathrm{~dB}$. This level has not been ratified by the government.

If all noise targets are to be reached using noise walls along the track, the walls would have to be 10 meters high. That is, of course, an esthetically unacceptable impact, so instead they suggest setting up 2-3 meter high noise walls along the railroad and, in addition, noise walls in the 300 nearest gardens around their patios. This would fulfill the target value $55 \mathrm{dBA}$ for patios, but probably not longer than until 2020, when it is expected to go into effect (the prognosis period). That year the capacity of the four tracks will be filled to $2 / 3$. What happens after that? The municipality argues that the traffic will continue to increase after 2020. The railroad company seems to take no responsibility for protection from extended noise after this point in time, as their noise calculation does not consider the extension of noise after 2020. In this matter, the railroad company is in fact breaking the law. The Environmental Act says that full future use must be considered concerning noise protection, since no further permit is needed when traffic increases and passes the estimated level in 2020. They also do not consider the fact that noise comes from the motorways and disturbs the people of Åkarp. The EU suggests that overlaying noise from two sources be considered when dimensioning noise protection in new infrastructure projects. The consequence is high noise in the other parts of the gardens and in the town as a whole, including parks and other green areas intended for recreation and stress reduction.

The municipality concerned wants to have solved the noise problems for the distant future with a tunnel that will cost 1 billion Swedish crowns (140 million USD) more than the surface terrace alternative. The railroad developer has tried to reach acceptance for a compromise, a five-meter below-the-surface terrace for the tracks. The municipality, however, has not accepted the below-the-surface compromise. The railroad company then returned to the surface alternative, and will ask the Government for a permit for that alternative. 
One of the most critical arguments in the debate is the estimation of noise impact. With the extra two tracks, the number of trains may increase from 335 today to a maximum capacity of around 800 in the distant future. Then, the duration of high noise passages, those without a stop, may be 3-4 hours per 24 hours. Today, the high noise lasts a total of one (1) hour per 24 hours. As a point of comparison, the duration of high noise in Gothenburg and Stockholm reaches a maximum of about half an hour $(0.5$ $\mathrm{h} / 24$ hours) The municipality argues that the traditional way of calculating train nose, "equivalent" (average) noise and "maximum" noise, will evade the real experienced noise effects of the future.

Measures such as equivalent noise (LAeq, 24h XX dB) do not make understanding and comparing different noise situations easy. There is a need to develop more pedagogic, understandable and illustrative ways of explaining noise situations. Two new tools have been developed in the context of this case. One tool is a visualization of the noise using computer techniques. One student (John Wadbro) has produced a film in which he visualizes the noise "bubbles" from trains passing trough the city on the same map on which he also shows the noise from the motorways. The film ${ }^{12}$ is very pedagogic, as it shows the instantaneous noise" from both sources using same classification and color coding for the noise level, and using the length and frequency of trains corresponding to the future situation. Normally it is very difficult to compare road traffic noise and train traffic noise as they appear so differently. The equivalent measure (average noise) for trains is difficult to translate to the real situation because trains pass intermittently.

Another tool is the "sum of high noise duration time" throughout the twenty-four hour day. That is the total duration of time in which trains are passing a town without stopping. Such passages usually cause a noise level of 90-100 dBA at the platform beside the track. Already today, Åkarp has a "sum of high noise duration time" double as long as that at the most frequently used railroad passages in other regions of Sweden. The municipality estimates that the sum of high noise duration time in Akarp will increase from one hour up to four hours per twenty-four hour period at maximum usage of the total capacity of four tracks in the distant future. That is about eight (8) times more than at the most frequented railway passages in the regions of Stockholm and Gothenburg today.

The railroad company is required by law to prove that this will not cause significant damage to the public health in Akarp. It is doubtful that they can do this, however, since such a high frequency of trains combined with

1 (http://kurs.slu.se/kurser/LP0358/10086.0405/presentation.html) 
such a large number of long freight trains probably has never occurred in Sweden in the past.

The valley topography of $\AA$ karp causes inversion on many evenings and nights, with layers of different temperatures that reflect high noise even down to houses far from the railroad (Figure 5).

The most important facts in the debate are provided by research on people's stress and well-being as related to their outdoor environment. Current research conducted by, among others, Patrik Grahn's research group provides strong evidence to support the notion that certain quality of sound may reduce stress (Grahn and Stigsdotter 2003). The quality of sound and level of noise are significant in assigning most of the eight characteristics. The total area of parks per inhabitant today fulfilling the accepted threshold of noise level as defined by SNV (The Swedish Environmental protection Agency) is zero (0!).

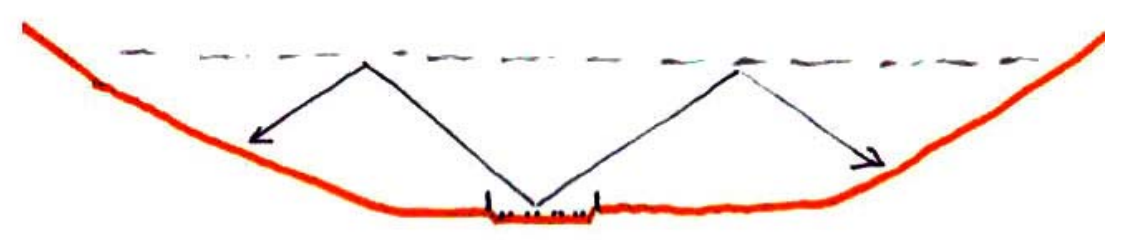

Figure 5. Different temperatures can reflect noise a great distance from the railroad with an extension of $20 \mathrm{dBA}$.

Concerning the eight characteristics, the parks of Âkarp have been evaluated with respect to the differences between the "covered" situation (tunnel) and "open" alternatives ("surface terrace" and "below-the-surface terrace") (Figure 6). An open solution prohibits many characteristics in most of the parks in Akarp. With a tunnel, if a complete variety of characteristics is to be promoted, the greatest emphasis should be put on central tunnel parks, that in the future will be able offer the full scope of the eight characteristics. Areas around the new train station, Stationsparken and the neighborhood around the Business and Industry Park, provide such characteristics as Lush, Rich in species, Spacious, Festive and Culture. Due to its dense population, this area will never have the characteristic Serene. Further away from the station, there is potential to develop characteristics such as Rich in species, Space, the Common, the Pleasure Garden and Culture. In order to provide the missing characteristics of this central park in a third "nature" park in Åkarp, emphasis should be put on characteristics such as Serene, Wild and Spacious.

The characteristics Serene and Spacious can also be ensured by lowering the traffic noise level for the park in nearby Alnarp. With the 
tunnel alternative through Åkarp, the noise level will decrease in the Alnarp Park as well, as the trains will descend into the tunnel already 1.5 kilometer from the tunnel entrance near Alnarp Park. The railroad company could also lower the total noise exposure by putting up noise walls along the motorways around Åkarp. Such an effort would be defined as "replacement compensation measures" for the railway extension project. In this way, a balance could be reached concerning the health function of nature and landscape as compared with the previous period of the 1960s, which offered an acceptable noise level at that time (Figure 7).

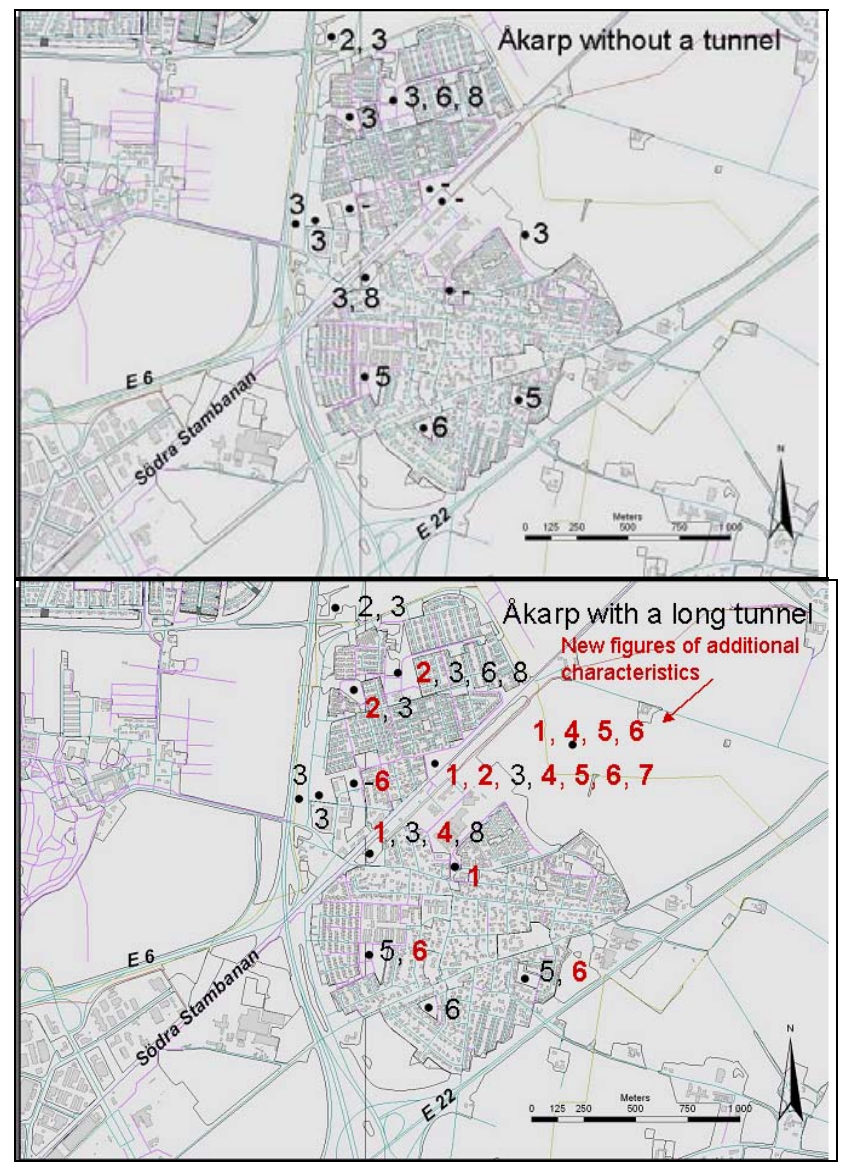

Figure 6. The eight characteristics in parks with an open railroad (above) and tunnel (under). Significant is that the characteristic serene is not possible without a tunnel A $1.7 \mathrm{~km}$ tunnel would enable creation of a "silent" area in Åkarp of benefit to human health and well-being. (Anna Johansson, Burlöv municipality and Erik Skärbäck 2004). 


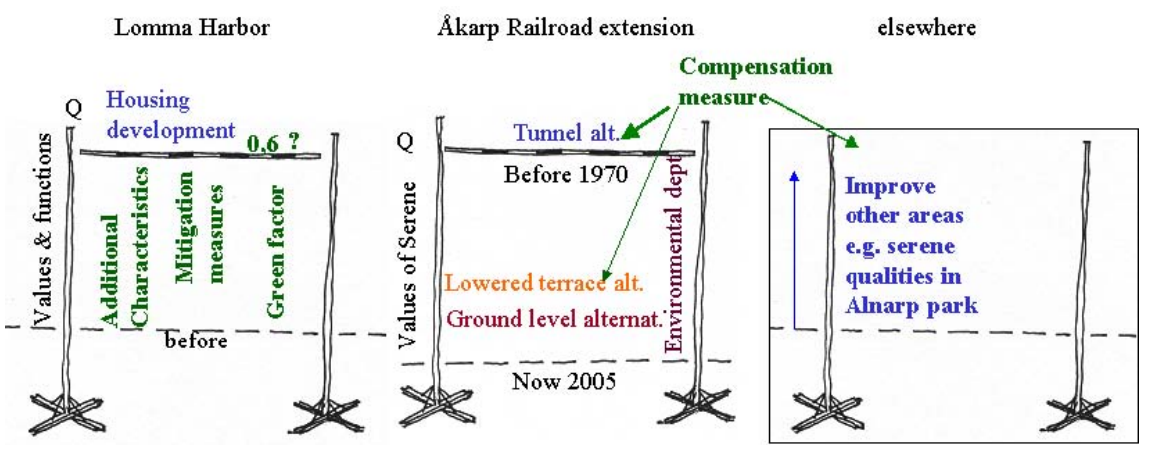

Figure 7. With a tunnel, a complete variety of characteristics would be promoted. The characteristics serene and spacious may perhaps also be ensured by lowering the traffic noise level at the park in nearby Alnarp, as a compensation measure.

\section{Discussion and conclusions}

The Lomma Harbour Project was named "Planning Project of the year 2004" by the Swedish Association of Architects. One main conclusion of this study is that legal methods to move developers in an environmentally positive direction are not always necessary. Environmental concerns seem more and more to be a sales factor, and in such cases profit, resulting from increasing customer demands for "health qualities", is as good an incitement for quality improvement as is force through regulations.

The widening of the railroad through Âkarp in the municipality of Burlöv illustrates the close relationship in infrastructure planning projects between scientific environmental investigations and financial/political decisions. This is not a new phenomenon, but how much may it cost? More interesting, however, is the question: Who will pay? And even more interesting is the question: What environmental qualities constitute the minimum standard that meets the basic needs of public health?

Is it possible to estimate the environmental benefits of a tunnel to be so high that one can politically defend an extra budget of 1 billion Swedish crowns? That is one main struggle. The municipality explains, using data from SCB (Statistics Sweden), that the value of houses in Åkarp has been suppressed the past 40 years by an average of 0.5 million Swedish crowns as compared with the neighboring city Lomma, and that a tunnel would partly restore the house values. In addition, the tunnel offers attractive sites for another thousand new homes very close to the railway. Dwellings close 
to public transportation stations are one criterion for a sustainable city in the future.

The reality for expensive political decisions, however, is not that simple. Long-term investigations seldom result in short-term political votes, and very few voters live in little Åkarp. This raises an interesting ethical question. Who should pay for the future environmental earnings a tunnel would provide? Can the present villagers require the railroad company to consider the environmental costs of suppressed house prices during the past 40 years? Can the municipality argue that building a tunnel is a way of paying back the dept owed for stolen environmental values over the past 40-year period of increasing noise in Åkarp? Can the railroad company, on the other hand, argue that the opportunities provided by a tunnel to develop attractive sites for a thousand or so new homes, very close to the railway station, would result in such good business for the municipality that the municipality should pay most of the tunnel costs? Can the state expect relatively few people in the town today to pay for the tunnel to enable mass urbanization occurring years after their death? Since Åkarp is situated at the center of a university region, a sustainable development with a high standard of serene qualities is expected to fulfill demands of the mobile well-educated staff of hightech enterprises. In fact one criterion for obtaining a permit, according to the Swedish Environmental Act, is that the developer must economize and consider special resources of national interest. The municipality argues that, in this very accessible zone between Lund and Malmö, the large area (40 ha) of potential housing development close to the railroad would be a national resource if a covered tunnel were built. Åkarp is only 10 minutes away from three universities, so the location would provide competition to Copenhagen in attracting multinational firms. Thus, local environmental concerns in infrastructure projects, I assume, are not always merely local environmental issues, but are sometimes issues of interest for the national income.

From a methodological point of view an interesting question is whether or not the high noise level in Åkarp can be balanced with compensatory measures such as noise reduction in Alnarp Park, which is on average 1.5 kilometers away from inhabitants' homes (Figure 7). Serene is a very important characteristic, but as Grahn and Stigsdotter (2003) point out, the distance should preferably not be longer than 500-1000 meters. 


\section{References}

Atkinson RL, Atkinson RC, Smith EE, Bem DJ, Nolen-Hoeksema S (1996) Hilgard's Introduction to Psychology. Harcourt Brace College Publishers, Fort Worth.

Large Projects (2004) LP0358 EIR and landscape balancing in large projects, 10 credits (15 ECTS credits).

http://www.slu.se/page.cfm?page $=371$ andKurskod=LP0358andengelska=true and

Benediková J (2004) Lomma Harbour Project - Strandfuret Forest, EIR and Landscape balancing in large projects, http://kurs.slu.se/kurser/LP0358/10086.0405/JitkaBenedikovareport.pdf, Department of Landscape Planning, SLU Alnarp.

Berggren-Bärring A-M, Grahn P (1995) Grönstrukturens betydelse för användningen. En jämförande studie av hur människor i barnstugor, skolor, föreningar, vårdinstitutioner $\mathrm{mfl}$. organisationer utnyttjar tre städers parkutbud. (licentiatavhandling för Berggren-Bärring.) Landskapsplanering Rapport, 95:3. Sveriges lantbruksuniversitet, Alnarp.

Berglund B, Lindvall T, Schwela DH (eds) (2000) Guidelines for Community Noise. World Health Organization (WHO), Geneva.

EIR (2004) Southern Main Line Håstad - Arlöv, Environmental Impact Assessment for the rail survey, Swedish National Rail Administration, Southern Track Region, 2004-09-14 (Södra Stambanan Håstad-Arlöv, Miljökonsekvensbeskrivning tillhörande järnvägsutredning 2004-09-14.)

Eliasson J (2005) Variations in valuations of noise and intrusion effects. Are stated choice results compatible with hedonic prices? Transport Reviews. In press.

Eliasson J, Lindqvist Dillén J, Widell J (2002) Measuring intrusion valuations through stated preference and hedonic prices: a comparative study. In: European Transport Conference 2002, PTRC, London.

Evans GW, Bullinger M, Hygge S (1998). Chronic noise exposure and physiological response: A prospective study of children living under environmental stress. Psychological Science 9: 75-77

Gidlöf Gunnarsson A, Öhrström E (2005) Noise and general well-being in urban environments:

Grahn P (1991) Om parkers betydelse. Dissertation. Department of landscape planning, SLU and Movium: Stad and Land 93, Alnarp.

Grahn P (1994) Green structures - The importance for health of nature areas and parks. European Regional Planning 56: 89-112

Grahn P, Berggren-Bärring A-M (1995) Experiencing parks. Man's basic underlying concepts of qualities and activities and their impact on park design. In: Ecological Aspects of Green Areas in Urban Environments. IFPRA World Congress, Antwerp Flanders, Belgium 3-8 September 1995. Chapter 5, pp $97-$ 101. 
Grahn P, Larsson C (1997) Stadens grönområden. Hur de används och vad som tilltalar besökarna. Department of landscape planning, Alnarp.

Grahn P, Stigsdotter U (2003) Landscape planning and stress. Urban Forestry and Urban Greening 2: 1-18.

Grahn P, Stigsdotter U, Berggren-Bärring A-M (2005) A planning tool for designing sustainable and healthy cities. The importance of experienced characteristics in urban green open spaces for people's health and well-being. In: Conference proceedings "Quality and Significance of Green Urban Areas", April 14-15, 2005, Van Hall Larenstein University of Professional Education, Velp, The Netherlands

Jacobsson K (2004) Sorgenfri Industrial area. EIR and Landscape balancing in large projects, http://kurs.slu.se/kurser/LP0358/10086.0405/KarinJacobsson.pdf. Department of Landscape Planning, SLU Alnarp.

Öhrström E, Skånberg A, Barregård L, Svensson H, Ängerheim P (2005a) Effects of simultaneous exposure to noise from road- and railway traffic. Invited paper to appear in "Inter Noise 2005", Rio de Janiero 6-10 augusti, 2005.

Öhrström E, Skånberg Svensson H, Gidlöf Gunnarsson A (2005b) Effects of road traffic noise and the benefit of access to quietness. Manuscript submitted to "Journal of Sound and Vibration" January 2005.

Östlund N (2005) Communicating physical planning - expanding democracy via internet. In: Inspiring Global Environmental Standards and Ethical Practices. Conference proceeding at the 30th Annual Conference of NAEP (National Association of Environmental Professionals). Alexandria, Virginia, April 2005.

Ottosson J, Grahn P (1998) Utemiljöns betydelse för äldre med stort vårdbehov. Licentiatavhandling för Ottosson, J. Stad and Land nr 155. Alnarp.

Rundcrantz K, Skärbäck E (2003) Environmental Compensation in Planning, A review of five different countries with major emphasis on the German system. European Environment 13: 204-226

Skärbäck E (2003) Balanseringsprincipen för Lomma hamn. http://www.lomma.se/lommahamnprojektet/projektet/ planhandlingar.4.dca7d0ffbb

Skärbäck E (2005a) Landscape as a Resource for Health and Development - Case studies. In: Inspiring Global Environmental Standards and Ethical Practices. Conference proceeding at the 30th Annual Conference of NAEP (National Association of Environmental Professionals). Alexandria, Virginia, April 2005.

Skärback E (2005b) The potential role of nearby natural areas. Paper delivered at the conference "Life in the Urban Landscape", Gothenburg 30 May to 4 June, 2005.

Skärbäck E (1997) Is the method of balancing a potential tool for the protection and rehabilitation of landscape? A comparison of eastern Germany and southern Sweden. Paper and presentation at the International Conference "Urban, Regional, Environmental Planning and Informatics to Planning in an Era of Transition”, Athens October 22-24, 1997, Technical Univ. Athens. 
Stigsdotter U (2005) Urban green spaces: promoting health through city planning. In: Conference proceedings "Inspiring Global Environmental Standards and Ethical Practices" National Association of Environmental Professionals, NAEP $30^{\text {th }}$ Annual Conference, April 16-19, 2005, Alexandria, Virginia

Stigsdotter UA, Grahn P (2003) Experiencing a Garden: A Healing Garden for People Suffering from Burnout Diseases. Journal of Therapeutic Horticulture 14: $38-48$

Stigsdotter U, Grahn P (2004) A garden at your doorstep may reduce stress: private gardens as restorative environments in the city. In: Open Space: People Space; an international conference on inclusive environments. 27-29 October 2004, Edinburgh Scotland.

http://www.openspace.eca.ac.uk/conference/proceedings/summary/Stigsdotter.htm Törnqvist G (1978) SOU 1978:18 Öresundsförbindelser.

Ulrich RS, Simons RF, Losito BD, Fiorito E, Miles MA and Zelson M (1991). Stress Recovery During Exposure to Natural and Urban Environments. Journal of Environmental Psychology. 11: 201-230.

UNCED (1992) Agenda 21. Conches, Switzerland: United Nations Conference on Environment and Development. 